\title{
The proposed Investment Court System: does it really solve the problems? ? $^{* *}$
}

\section{La propuesta de un Sistema de Corte de Inversiones: ¿realmente resuelve los problemas?}

\begin{abstract}
In recent years, the foreign investment regime has been subject to an increasing volume of criticism from the public. The significant sums of money at stake and the potential impact of the awards on State's regulatory powers have placed the Investor-State Dispute Settlement (ISDS) under the spotlight. In response to this, the European Union has proposed a far-reaching reform which introduces an Investment Court System (ICS). This model constitutes an innovative dispute settlement mechanism intended to address most of the core issues of the ISDS by combining elements of the traditional ISDS with judicial features. Overall, this paper aims at analysing whether the EU's new approach constitutes an effective improvement to the traditional ISDS and the future of the international investment regime. To achieve this, the study begins with an overview of the current ISDs; followed by a synopsis of the main criticisms to the traditional ISDS; proceeded by a review of the core features of the EU's proposed ICs and its inclusion in the new generation of IIAS in negotiation by the EU; and finally, provides a commentary of the main criticisms and obstacles that the introduction of the ICs is likely to encounter.
\end{abstract}

KEYWORDS

Investment Court System (ICS), Investor-State Disputes Settlement (ISDS), Foreign Direct Investment (FDI), International Investment Agreement (IIA),

LL.M. (Master of Laws) en Resolución de Disputas Internacionales de King's College London. Magíster en Gobierno y Políticas Públicas de la Universidad Externado de Colombia. Abogado de la Universidad Externado de Colombia. Investigador independiente. Londres, Inglaterra. Contacto: juanpablo.charris@gmail.com

** Recibido el 11 de septiembre de 2017, aprobado el 4 de abril de 2018.

Para citar el artículo: ChARRIS BenEDETTI, J. P. The proposed Investment Court System: does it really solve the problems? En Revista Derecho del Estado, Universidad Externado de Colombia. N. ${ }^{\circ} 42$, enero-abril de 2019 , pp. 83-115.

DOI: https://doi.org/10.18601/01229893.n42.04 
Comprehensive Economic and Trade Agreement (CETA), Transatlantic Trade and Investment Partnership (TTIP).

RESUMEN

En los últimos años, el régimen de inversión extranjera ha sido objeto de un creciente número de críticas del público. Las sumas significativas de dinero en juego y el posible impacto de los laudos en los poderes regulatorios del Estado han puesto al actual Sistema de Resolución de Controversias entre Inversores y el Estado bajo la lupa. En respuesta a ello, la Unión Europea ha propuesto una reforma de gran alcance mediante la introducción de un Sistema de Corte de Inversiones (SCI). El nuevo sistema constituye un mecanismo innovador de resolución de controversias internacionales destinado a remediar los problemas centrales que acarrea el sistema actual, mediante la combinación de elementos tradicionales del arbitraje con rasgos judiciales. En este contexto, el presente escrito pretende analizar si el nuevo enfoque de la Unión Europea constituye una mejora efectiva del actual mecanismo de resolución de controversias de inversiones y del futuro del régimen de inversión internacional. Para dicho propósito, el artículo comienza con una descripción general del actual Sistema de Resolución de Controversias entre Inversores y el Estado; seguido de una sinopsis de sus principales críticas; continúa con un resumen de las principales características del Sistema de Corte de Inversiones, así como de su inclusión en la nueva generación de acuerdos internacionales de inversión en negociación por la Unión Europea; y, finalmente, hace una referencia a las principales críticas y posibles obstáculos que afrontará la introducción del nuevo Sistema de Corte de Inversiones.

PALABRAS CLAVE

Sistema de Corte de Inversiones, Sistema de Resolución de Controversias entre Inversores y el Estado, Inversión Extranjera Directa, Acuerdos Internacionales de Inversión, Acuerdo Económico y Comercial Global (AECG), Asociación Transatlántica de Comercio e Inversión.

\section{CONTENT}

Introduction. 1. An overview of the ISDS. 1.1. The early years. 1.2. The foreign investment regime. 1.3. Rules and institutions. 1.4. Main features of the ISDS. 2. Criticism to the ISDS. 2.1. Lack of consistency. 2.2. Lack of impartiality. 2.3. Lack of transparency. 3. The introduction of the ICs. 3.1. The EU's new investment policy. 3.2. The core institutional features of the ICS. 3.3. The venture towards a Multilateral Investment Court System. 4. Criticism to the 
ICS. 4.1. Re-politicisation. 4.2. Quality of the decision-making. 4.3. Finality, efficiency and costs. 4.4. Enforceability. Conclusions. References.

\section{INTRODUCTION}

Contemporary international investment agreements tend to articulate substantive standards of protection that confer foreign investors the right to bring claims against sovereign States before international arbitral tribunals. This mechanism of dispute resolution is known as investor-state-dispute settlement (ISDS).

Nevertheless, in recent years, the legitimacy of the ISDs has been subject to numerous criticisms. In this context, critics seek for structural reforms to the system, while supporters of the status quo advocate for the need to maintain the core elements of the system with some amendments.

Some of the critiques to the ISDS stem from tribunals rendering contradictory decisions, the potential conflict of interest of individuals acting as counsellors and arbitrators in similar cases, and the apparent detriment of democratic institutions in favour of private interests. However, although previous attempts to reform have been dismissed as premature and politically challenging, recent developments within the European Union (EU) have gained momentum in favour of a major shift in the system, encouraged by the adoption of a permanent court system for the resolution of investmentrelated disputes.

Thus, the present study is based upon the EU's proposal for the introduction of an Investment Court System (ICS), analysed both from an institutional and a procedural perspective. In this sense, the goal is to determine whether the implementation of the ICS - as proposed by the EU for the Transatlantic Trade and Investment Partnership (TTIP), already included in the EU-Vietnam Free Trade Agreement and the EU-Canada Comprehensive Economic and Trade Agreement (CETA), and more recently in the EU-Singapore Investment Protection Agreement and the EU-Mexico Trade Agreement, and currently subject to bilateral negotiation in the EU-Japan Economic Partnership Agreement - constitutes an improvement to the current ISDS.

For this purpose, the paper is divided into four complementary sections: first, (1) an overview of the current ISDS; second, (2) a synopsis of the main criticisms to the traditional ISDS; third, (3) an outline of the core features of the EU's proposed Investment Court System; and, finally, (4) a reference to the main criticisms and obstacles that the introduction of the ICs is likely encounter. 


\subsection{The early years}

The advent of the international investment regime constituted a significant improvement in terms of protection of foreign investment against governmental actions. Before its establishment, foreign investors willing to challenge actions or omissions in the country of their investment had to rely on unfamiliar national proceedings and often biased national courts. Alternatively, investors could resort to diplomatic protection from their home country, which at times was uncertain and problematic as it often entailed other political interests beyond the legal dispute. ${ }^{1}$

Following the culmination of World War II, capital exporting countries began incorporating standards of protection for foreign investors against noncommercial risks such as expropriation and other forms of discrimination in international treaties. These protective legal grounds operated as safeguards to mitigate the risks of investing in countries with high level of corruption, systems of political patronage and weak institutions. ${ }^{2}$

Initially, these rights were included in general trade treaties such as the "friendship, commerce and navigation" treaties promoted by the United States. However, by the late 1950s, some European countries like Germany, France, Switzerland and the Netherlands began concluding treaties exclusively orientated towards investment, a practice later followed by the US. ${ }^{3}$ These investment-focused treaties regularly involved two countries and became known as Bilateral Investment Treaties (BITs).

By the late 1980s, the need from developing countries to attract Foreign Direct Investments (FDI) to incentivise the development of infrastructures and services and optimise State businesses, presented an open invitation to capital exporting countries and contributed to the promulgation of BITs. In this sense, the agreement was clear: in return of FDI, host States would agree for arbitration to be the dispute settlement mechanism in investment disputes. ${ }^{4}$

Accordingly, the vast majority of BITs entered into force in the early 1990s and, as a result, the late 1990s and early 2000s experienced an investor-

1 KoEth, W. Can the Investment Court System (ICS) save TTIP and CETA. European Institute of Public Administration (EIPA) Working Papers, 2016. Available at: http://publications eipa.eu/ en/details/\&tid=1860 (Accessed 16 August 2017), 3.

2 WebB Y AсKeE, J. Toward a Minimalist System of International Investment Law. Suffolk Transnational Law Review. Vol. 303, 2009, 305-306.

3 Ibid., p. 306.

4 Stone Sweet, A., Chung, M. and Saltzman, A. Arbitral Lawmaking and State Power: An Empirical Analysis of Investment Arbitration. Available at: https://ssrn.com/abstract=2919723 (Accessed 17 July 2017), 3. 
state arbitration boom and the exponential development of investment law throughout the globe. ${ }^{5}$

\subsection{The foreign investment regime}

There are currently over 3000 international investment agreements (IIAS) in force, from which BITs are the primary source of international legal protection for foreign investors. This broad category of IIAS is complemented by Free Trade Agreements (FTAs), such as the North American Free Trade Agreement (NAFTA) and the Energy Charter Treaty (ECT), which contain investment chapters articulating substantive standards and international arbitration as the dispute settlement mechanism. ${ }^{6}$ Furthermore, following the trend of investment promotion, States have also adopted national legislation offering arbitration for the settlement of foreign investment disputes.

Although there are differences in scope and terminology between the numerous IIAS, the majority of modern investment treaties share common features. First, they adopt substantive standards for the protection of FDI, including: the prohibition of direct and indirect expropriation without fully, adequate and prompt compensation; principles of non-discrimination from domestic investors ('national treatment') and from third countries investors ('most-favoured nation treatment'); the right to be treated in accordance with customary international law ('minimum standard of treatment'); the right to receive diligent protection from physical assaults to personnel and facilities ('Full Protection and Security'); and a wide range of guarantees including due process and respect of investor's legitimate expectations from given undertakings as well as a stable legal framework ("fair and equitable treatment'). ${ }^{7}$ Second, they confer investors the opportunity to bring claims for the violation of these standards against host States before arbitral tribunals. ${ }^{8}$ Third, they provide for compensation in the form of monetary awards instead of the reversal of laws or administrative decisions. ${ }^{9}$

These treaties adopt mixed arbitration as the mechanism to resolve investment-related claims, commonly known as Investor-to-State Dispute Settlement (ISDS). Essentially, ISDS allows foreign investors to initiate legal proceedings against a sovereign State when the latter has allegedly breached its commitments under an IIA. These cases are adjudicated by an arbitral panel

5 WeBв Y AсKeE. Toward a Minimalist System of International Investment Law, cit., 307.

6 Ibid., p. 309.

7 Ibid., p. 307.

8 Stone Sweet, Chung and Saltzman. Arbitral Lawmaking and State Power: An Empirical Analysis of Investment Arbitration, cit., 3.

9 Collins, D. A. The UK should include Investor State Dispute Settlement (ISDS) in its Post-Brexit International Investment Agreements. 2017, 3. SSRN Electronic Journal: https://ssrn. com/abstract $=2924051$ 
composed of experts selected by common accord by the conflicting parties on an ad hoc basis. ${ }^{10}$

\subsection{Rules and institutions}

ISDS may take place before different institutions and can be governed by a variety of arbitral rules by reference to the applicable IIA. Typically, ISDS is offered in conjunction with a choice of forum between the International Centre for the Settlement of Investment Disputes (ICSID) and the United Nations Commission for International Trade Law Rules (UNCITRAL) administered by the Permanent Court of Arbitration (PCA) or an ad hoc tribunal. Additionally, it can be managed by other arbitral house operating under its own rules, such as the International Chamber of Commerce (ICC), the London Court of International Arbitration (LCIA), the Stockholm Chamber of Commerce (SCC), and the Singapore International Chamber of Commerce (SICC), among others.

Furthermore, international treaties governing the recognition and enforcement of arbitral awards such as the Convention on the Recognition and Enforcement of Foreign Arbitral Awards (New York Convention of 1958) and the Convention on the Settlement of Investment Disputes between States and Nationals of Other States (ICSID or Washington Convention of 1965), have ensured that the awards rendered by the arbitral tribunals are enforceable against host States and difficult to challenge in their domestic courts. ${ }^{11}$ Under the New York Convention, which currently lists 159 States parties, ${ }^{12}$ an award issued in a Contracting State can be freely enforced in any other Contracting State, limited to specific grounds for challenge through local courts. On the other hand, under the Washington Convention, which currently lists 153 State parties ${ }^{13}$, an award is automatically enforceable in an ICSID State, only subject to an annulment proceeding set out within the Convention.

In practice, ICSID is by far the most referred arbitral forum for investment disputes. ${ }^{14}$ Tailored to promote the settlement of investment disputes, ${ }^{15}$ it was established by the ICSID Convention in 1965 as a delocalised facility under the auspices of the World Bank. ${ }^{16}$ In this sense, ICSID is an institutional framework that facilitates the conduct of arbitration but does not provide substantive law,

10 Koеth. Can the Investment Court System (ICS) Save tTIP and CETA, cit., 3.

11 WeвB Y ACKEE. Toward a Minimalist System of International Investment Law, cit., 307.

12 See the full list of Contracting States in: http://www.newyorkconvention.org/countries (Accessed 25 June 2018).

13 See the full list of Contracting States in: https://icsid.worldbank.org/en/Pages/about/ Database-of-Member-States.aspx (Accessed 25 June 2018).

14 Arbitral Rules - Investment Dispute Settlement Navigator (Investmentpolicyhub.unctad. org, 2017). Available at: http://investmentpolicyhub.unctad.org/ISDS/FilterByRulesAndInstitution (Accessed 20 September 2017).

15 Preamble to the ICSID Convention.

16 Article 2 of the ICSID Convention. 
a role that is left to the parties by reference to the IIA applicable to the dispute. Additionally, the ICSID framework is regulatory self-contained, operating by exclusive reference to the Convention and Rules. ${ }^{17}$

Another distinctive feature of the ICSID framework is that, according to Article 54 of the ICSID Convention, domestic courts of member States are required to recognise ICSID awards in the same way they would implement a judgment from their own highest Court. This is particularly relevant considering that the Convention is currently ratified by most States in the world and that it operates as an Administrative structure of the World Bank.

Regarding disputes falling outside of the scope of the ICSID Convention, parties may resort to ICSID Additional Facility, created in 1978 and reviewed in 2006. In such cases, disputes are administered by the Secretariat of the Centre and may benefit from its institutional support and expertise, although the recognition and enforcement of the awards in such cases would be governed by the New York Convention. ${ }^{18}$

On the other hand, there are a number of non-ICSID arbitral institutions available to administer the settlement of investment disputes, such as the above-mentioned ICC, LCIA, SCC and SICC, which operate under their own arbitral rules or by reference to the UNCITRAL Rules. In such cases, having a seat of arbitration, these arbitral houses maintain a strong connection to the country in which the institution is based, whereby the proceedings are influenced by the legislation in place and the enforceability of the awards is governed by the New York Convention. ${ }^{19}$

\subsection{Main features of the ISDS}

The popularity of the ISDS can be attributed to three distinctive features that have made the system particularly convenient for the resolution of investmentrelated disputes with a cross-border component.

First, the implementation of investor-State arbitration. Noteworthy, arbitration is a flexible and pragmatic procedure that facilitates parties' autonomy. In this sense, parties are free to select the Rules applicable to the controversy, the arbitrators hearing their case, the institution that is going to supervise the proceedings and the language in which the proceedings are to be conducted in. Consequently, arbitration aims at ensuring impartiality in

17 Process Overview (Icsid.worldbank.org, 2017). Available at: https://icsid.worldbank. org/en/Pages/process/Overview.aspx (Accessed 6 July 2017).

18 ICSID Additional Facility Rules (Icsid.worldbank.org, 2017). Available at: https://icsid. worldbank.org/en/Pages/icsiddocs/IcsiD-Additional-Facility-Rules.aspx (Accessed 4 July 2017).

19 Butler, N. Possible Improvements to The Framework of International Investment Arbitration. The Journal of World Investment \& Trade. Vol. 14, 2013, 632. 
the decision-making, offering the parties equal opportunities in defending their legal causes and providing binding decisions. ${ }^{20}$

Second, the finality of the awards. This feature implies that the losing party has limited rights to challenge the award, enabling disputes to be solved in an efficient and cost-effective manner. Accordingly, ICSID provides for annulment proceedings rather than appeals, the difference being that "[a] nnulment of a decision simply amounts to nullification, usually due to some kind of abuse of process. Appeal, on the other hand, involves evaluating the substantive correctness of the decision, and may result in the replacement of the original decision with a new one". ${ }^{21}$ In this sense, Article 52 of the ICSID Convention provides five limited grounds for annulment, whereas in non-ICSID cases, awards may be challenged restrictively under Article 5 of the New York Convention.

Third, enforceability of awards. By virtue of the Washington Convention, awards are automatically enforceable in all Member States of the ICSID Convention. On the other hand, under the New York Convention, awards are enforceable unless they contravene national law and public policies. Consequently, arbitral awards are easier to enforce internationally in comparison to judgments of national courts, as the latter are limited to reciprocal enforcement arrangements. ${ }^{22}$

\section{CRITICISM TO THE ISDS}

In recent years, the foreign investment regime has been subject to an increasing volume of criticism from host States and the public. The significant sums of money at stake and the potential impact of the awards on State's regulatory powers have placed the ISDS under the spotlight.

The criticism to the ISDS can be summarised in three structural categories: 1) the lack of consistency in the decisions; 2) the lack of impartiality of the arbitrators; and 3) the lack of transparency of the proceedings, which will be analysed with more detail below.

20 ColLins. The UK should include Investor State Dispute Settlement (ISDS) in its PostBrexit International Investment Agreements, cit., 4.

21 ButLer. Possible Improvements to the Framework of International Investment Arbitration, cit., 631 .

22 Colnins. The UK should include Investor State Dispute Settlement (ISDS) in its PostBrexit International Investment Agreements, cit., 5. 


\subsection{Lack of consistency}

\subsubsection{Examples of inconsistency}

The problem of inconsistency derives from tribunals rendering contradictory decisions in cases involving similar sets of facts, parties and applicable IIAs.

A notable example of inconsistency is found in the Lauder cases ${ }^{23}$ in which different UNCITRAL tribunals dealing with the same factual background, almost identical Claimants, and similar applicable standards of protection, with the only difference being that the proceedings were brought under different treaties, reached dramatically opposite decisions. The first arbitration was initiated by Mr Lauder, the controlling shareholder of CME, as an American investor under the US-Czech BIT. The second was brought by CME, as a company registered in the Netherlands by reference to the Dutch-Czech BIT. While the London-based Tribunal dismissed the expropriation claims, the Stockholm Tribunal found that the Czech Republic had committed expropriation, awarding \$355 million in damages. Regardless of the arguable 'correct' decision, it is clear that the contradictory results evidenced the structural shortcomings of the system. ${ }^{24}$

Another example of inconsistency is found in the SGS cases ${ }^{25}$ in which different ICSID Tribunals interpreted aversely the content of the 'umbrella clause', applicable to similar facts, although articulated in different treaties, i.e. the Switzerland-Pakistan BIT and Switzerland-Philippines BIT. While the SGS-Pakistan Tribunal adopted a restrictive interpretation, ${ }^{26}$ the SGS-Philippines Tribunal implemented an extensive interpretation. ${ }^{27}$ Since in these cases the applicable umbrella clauses were different versions contained in separate BITs, "the tribunal's contradictory approaches, on a conceptual level, are not as problematic as the two Lauder cases. But given the number of umbrella clauses within modern BITs, the practical consequences of the decisions are

23 CME Czech Republic B.V.v. Czech Republic, Ad hoc - uncitral Arbitration Rules, Partial Award of 13 September 2001, Final Award of 14 March 2003; and Lauder v. Czech Republic, Final Award, 3 September 2001, Ad hoc - UNCITRAL Arbitration Rules.

24 LaIrd, I. and Askew, R. Finality versus Consistency: Does Investor State Arbitration Need an Appellate System? The Journal of Appellate Practice and Process. Vol. 7, 2005, 299.

25 See SGS Société Générale de Surveillance S.A. v. Islamic Republic of Pakistan. ICSID Case No. ARB/01/13 (2003), Decision on Jurisdiction of 6 August 2003; and sGs Société Générale de Surveillance S.A.v. Republic of the Philippines. ICSID Case No. ARB/02/6 (2004), Decision on Jurisdiction of 29 January 2004.

26 In sGs-Pakistan the Tribunal stressed the need of "clear and convincing evidence" that the State parties to the BIT intended to transform contract breaches into treaty claims, in order to prevent every breach of contract to become automatically actionable before ICSID Tribunals .

27 In sGs-Philippines the Tribunal empathised in the lack of limitations in the wording of the umbrella clause and thus States "shall observe any obligation it has assumed with regard to specific investments in its territory by investors of the other". 
considerable". ${ }^{28}$ Ultimately, the SGS awards left States and investors without a clear understanding of the meaning and scope of the umbrella clause, contributing to a sense of uncertainty and unpredictability in the resolution of future disputes. ${ }^{29}$

Other examples of inconsistency are represented by a number of decisions such as Metalclad v. Mexico ${ }^{30}$ and S.D. Myers v. Canada ${ }^{31}$ in which the respective Tribunals interpreted differently the standard of 'fair and equitable treatment' (FET) contained in the same treaty, i.e. Article 1105 of NAFTA. While the Metalclad tribunal interpreted FET as an independent standard of protection, beyond the minimum standard of treatment under customary international law; the S.D. Myers tribunal levelled the standard as an element of the general rules of international law. Again, irrespectively of the correct approach to FET, the fact that Tribunals were not uniformly dealing with the meaning of FET under the same treaty implied unpredictability for the forthcoming disputes. ${ }^{32}$

\subsubsection{The need for an appellate body}

Experts believe that the 'crisis of consistency' in international investment arbitration could be addressed by introducing an appellate body. They believe that such instance would solve many of the current issues associated with inconsistency, including: a lack of predictability of the law, an absence of coherence within the field and the non-existence of the possibility of correctness in decision-making. ${ }^{33}$

The first issue to be addressed is the lack of predictability. Predictability derives from consistency, being the former a fundamental touchstone of any given legal system. ${ }^{34}$ Furthermore, the present lack of an appellate body to review the merits in cases of inconsistent decisions increases the sense of unpredictability, as there is no certain binding interpretation of reference. In this sense, critics have argued that " $[t]$ he mantra of one case not being binding on any other, each one being an individual, one-off, ad-hoc process, has no place in a legal system that passes judgment on a vast range of government

28 TAMs, C. J. Is there a Need for an ICSID Appellate Structure? 2009, 235. sSRN Electronic Journal: https://ssrn.com/abstract=1341268

29 Ibid.

30 Metalclad Corporation v. United Mexican States (2000). ICSID Case No. ARB(AF)/97/1 (2000).

31 S.D. Myers v. Canada (2000) ILM 1408 (NAFTA Arbitration).

32 Ibid.

33 ButLER. Possible Improvements to the Framework of International Investment Arbitration, cit., 632.

34 ManN, H. et al. Comments on ICSID Discussion Paper, "Possible Improvements of the Framework for ICSID Arbitration". International Institute for Sustainable Development (IISD), 2004, 6 . 
measures affecting international investments" ${ }^{35}$ Consequently, a review-tier body is envisaged to play a key role in consolidating predictable decisions.

The second issue refers to an absence of coherence in the practice of ISDS. This matter derives from the existence of a number of institutions and ad hoc tribunals settling investment-related disputes independently, without recourse to a single hierarchical authority with the capacity to unify approaches and interpretations ${ }^{36}$ Accordingly, there is currently no space left for systematic interpretations that integrate the different treaties in place. ${ }^{37}$

This situation is exacerbated by the current co-governance of multiple investment treaties and the ambiguous combination of customary international law and treaty law. In this sense, this fragmentation has promulgated differing tribunal interpretations and thus, prevented consistency. ${ }^{38}$ Accordingly, commentators have argued that "it would be beneficial to abandon the chaotic system of investment regulation, and strive towards the creation of a single, global overarching investment treaty". ${ }^{39}$

Therefore, some of the compelling reasons that support the need for an appellate facility stem from the following circumstances which, although valid, may hinder coherence: tribunals being limited to a formal duty to apply substantive law to a given applicable treaty; arbitrators coming from various backgrounds, specialities and preferences; and arbitrators being formally independent in every case. ${ }^{40}$

The third issue, which is one of the most recurrent criticisms to the ISDS, is the lack of a corrective instance available through appeal. Hence, some critics have favoured a two-tier body that could promote correctness, thus guaranteeing accurate decisions in case of faulty awards. In this sense " $[\mathrm{t}] \mathrm{he}$ investment appellate body could focus on the issues that divide the parties, and it would have the benefit of having before it one fully-reasoned decision" ${ }^{41}$

In sum, according to the critics, the introduction of an appellate mechanism would enable a greater level of consistency and coherence in the decision-making, which in turn would enhance predictability. Moreover, the introduction of a two-tier structure would prevent abuses to the system,

35 Ibid.

36 ButLer. Possible Improvements to the Framework of International Investment Arbitration, cit., 613.

37 Stone Sweet, Chung and Saltzman. Arbitral Lawmaking and State Power: An Empirical Analysis of Investment Arbitration, cit., 7-8.

38 TAMs. Is there a Need for an ICSID Appellate Structure?, cit., 236.

39 ButLer. Possible Improvements to the Framework of International Investment Arbitration, cit., 625-626.

40 Stone Sweet, Chung and Saltzman. Arbitral Lawmaking and State Power: An Empirical Analysis of Investment Arbitration, cit., 7-8.

41 TAMS. Is there a Need for an ICSID Appellate Structure?, cit., 240. 
such as forum shopping, by eliminating the option of looking for a "more convenient" interpretation of investment law. ${ }^{42}$

Nevertheless, experts have delimited two requirements to effectively develop an appellate body. First, it must be established as a single comprehensive appeal facility competent enough to hear appeals from all investment disputes, as multiple appellate bodies functioning in parallel would likely increase inconsistency. Second, it must be organised as a standing permanent body composed of a small number of arbitrators, as this would allow personal and institutional continuity to consolidate interpretations and legal developments. ${ }^{43}$

The fact that certain sectors within trade disputes have successfully adopted appeal options is a strong indicator of the potential benefits of such approach. In this way, the introduction in 1995 of an appellate body within the World Trade Organisation (WTO) framework, provided a hallmark in reaching consistent decisions on world trade law. In doing so, it has proven that "the appeals processes need not invite: (1) undue delays to the dispute resolution process, (2) increased costs for parties, or (3) an unmanageable caseload for the institution". ${ }^{44}$ Arguably, this example demystifies some of the alleged disadvantages and shows that the mechanism may offer efficient and cost-effective results.

\subsection{Lack of impartiality}

The traditional ISDS, inspired by the principle of party autonomy, promotes the selection of arbitrators by the contesting parties on an ad hoc basis. Consequently, the systematic issue with impartiality does not derive from the first designation of an arbitrator, instead, it stems from subsequent appointments and cases in which an arbitrator has previously defended investors' claims concerning similar legal issues.

In this way, the lack of impartiality is addressed by referring to the conflict of interest of individuals acting as counsellors and arbitrators in similar cases - building a sort of "international elite of arbitration" - together with the marked interest of arbitrators to be reappointed in future cases.

42 ButLER. Possible Improvements to the Framework of International Investment Arbitration, cit., 634 .

43 TAMs. Is there a Need for an ICSID Appellate Structure?, cit., 237-239.

44 Gleason, E. E. International Arbitral Appeals: What Are We So Afraid Of? Pepperdine Dispute Resolution Law Journal. Vol. 7, 2007, 273-275. Available at: http://digitalcommons. pepperdine.edu/drlj/vol7/iss2/5 (Accessed 17 July 2017). 


\subsubsection{Double-hat dilemma}

The first issue, known as "double-hat dilemma", refers to the concern regarding individuals acting both as counsellors and arbitrators in cases with similar legal issues, and to the absence of an ethical code of practice for professionals in the field ${ }^{45}$ In other words, there are no safeguards preventing inappropriate incentives that may flourish from the uncontrolled mixture of roles.

In this sense, commentators argue that the successive alternation of roles by professionals - acting indistinctively as arbitrators, counsellors, government representatives and expert witnesses - may jeopardise the delivery of impartial and independent justice. Consequently, in line with the 2014 UNCTAD Trade and Development Report, critics demand clear rules delimiting the different roles to avoid the risk of impartiality. ${ }^{46}$

Thus, the sense of impartiality resulting from the "double-hat dilemma" can be exemplified by the recurrent challenges to Yves Fortier by Venezuela. ${ }^{47}$ Regardless of the Tribunal's decision on the challenges, the situation brings to light the difficulties - real or apparent - that the current alternation of roles represents. In essence, among other allegations, Venezuela was unsatisfied with having an arbitrator that had recently departed from one of the law firms that had been consistently opposing to Venezuela before different forums.

\subsubsection{Reappointment}

The second issue is the alleged interest of arbitrators to be reappointed to subsequent arbitrations. In this sense, critics fear that arbitrators may be carrying hidden financial incentives to promote the proliferation of cases. In other words, by promoting investors' access to arbitrations, they may be enabling the growth of the industry and thus, the prospects of future reappointments for themselves. ${ }^{48}$

Additionally, it has also been argued that, as arbitrators are appointed by the parties, there could be a risk of them feeling implicitly bound to represent the interests of the appointing party, affecting the impartiality of their decisionmaking. Therefore, for some experts "the ad hoc nature of their appointment

45 Horvath, G. J. and Berzero, R. Arbitrator and Counsel: The Double-Hat Dilemma. Transnational Dispute Management (TDM). 2017. Available at: https://www.transnational-disputemanagement.com/article.asp?key=1985 (Accessed 19 August 2017).

46 unctad. Trade and Development Report. United Nations, 2014. Available at: http:// unctad.org/en/PublicationsLibrary/tdr2014_en.pdf (Accessed 8 July 2017).

47 For instance, see Fábrica de Vidrios Los Andes, CA y otros v. Venezuela. ICsid Case No. ARB/12/21.

48 Van Harten, G. Arbitrator Behaviour in Asymmetrical Adjudication (Part Two): An Examination of Hypotheses of Bias in Investment Treaty Arbitration. Osgoode Hall Law Journal. Vol. 50, 2012. 
is perceived by the public as interfering in their ability to act independently and to properly balance investment protection against the right to regulate" ${ }^{49}$

An example of perceived impartiality due to recurrent reappointments can be considered from Venezuela's appointment of Professor Brigitte Stern as arbitrator in seven different arbitration proceedings. Again, regardless of the results of the challenges, such circumstances raise concerns about the number of occasions an arbitrator could be appointed before it becomes suspicious.

Also, it has been pointed out that the rules of disclosure to prevent arbitrator impartiality are insufficient guarantees when settling sensible public and private interests in dispute. Therefore, critics advocate for "the need to move to a system that reflects the same judicial distance from the practice of law required of domestic judges making rulings on these matters". ${ }^{50}$

\subsection{Lack of transparency}

Critics have agreed on the lack of transparency present in the traditional ISDS . This problem is believed to stem from the fact that investment arbitration developed from commercial arbitration, where confidentiality is a guiding principle and one of its distinctive features.

\subsubsection{Public process}

For those opposing ISDS, it is shocking that, besides the ISDS, there is "[n]o other legal dispute settlement system under public international law [...] [that] either prevents the publication of its determinations or relies in whole or in part on the publication of selected portions of a decision" ${ }^{51}$ Consequently, there is an active demand for the adoption of complete, expedient and easily accessible publications of decisions and instances during the proceedings.

Nevertheless, the existence of a current trend aiming for transparency in international arbitration is undeniable given the public interests at stake. In this way, although most of the new IIAs have adopted the full publication in web-accessible versions of all documents and decisions, some treaties and institutions reluctant to transparency can still be found..$^{52}$

Furthermore, some experts insist on the benefits of confidentiality, by arguing that it allows parties to discuss openly amongst themselves in the search of solutions to their disputes, something that may be more difficult to achieve under the public eye. Yet, transparency could be maintained as

49 Malmström, C. Concept Paper: Investment in TtIP And Beyond-The Path for Reform. European Commission, 2015, 6.

50 Mann et al. Comments on ICSID Discussion Paper, "Possible Improvements of the Framework for ICSID Arbitration", cit., 11 .

51 Ibid., 8 .

52 Ibid. 
the general rule, allowing confidentiality only in exceptional circumstances, when deemed appropriate by the tribunal for the private discussion of sensitive information. ${ }^{53}$

\subsubsection{Amicus briefs}

Another important matter in the search for greater transparency relates to the implementation of a system of amicus briefs in investment arbitration. For supporters of this measure, contributions from a third party may assist the tribunal by bringing forward different arguments and sides to the controversy, helping avoid the current secrecy of the system.

Furthermore, this mechanism may contribute to transparency by exercising indirect public control whilst assessing the level of public accessibility to the cases. This way, transparency would become a pre-requisite for the amicus process, which would then be possible only in the case of people being aware of the disputes. ${ }^{54}$

Overall, through the given examples, detractors of ISDS have exposed the potential harming effects that arbitration entails to host States and their citizens, and the significant implicit sacrifices and risks when attracting foreign investment.

\section{THE INTRODUCTION OF THE ICS}

The criticism against the traditional ISDS encouraged the ICSID Secretariat to release, on 22 October 2004, the discussion paper "Possible Improvements of the Framework for ICSID Arbitration" for public comments, which contemplated, amongst other reforms, the creation of an appeal facility within the ICSID framework. ${ }^{55}$

Nevertheless, this idea was strongly opposed by the majority of ICSID members and, consequently, discarded - at least provisionally - by the ICSID Secretariat. This was supported by the publication, on 12 May 2005, of the working paper "Suggested Changes to the ICSID Rules and Regulations", in which, although acknowledging the need to further develop the proposed appellate mechanism, the ICSID Secretariat concluded that "it would be premature to attempt to establish such an ICSID mechanism at this stage, particularly in view of the difficult technical and policy issues raised in the Discussion Paper". ${ }^{56}$

53 Ibid., 10.

54 Ibid., 9.

55 International Centre for Settlement of Investment Disputes. Possible Improvements of the Framework for ICSID Arbitration. ICSID Secretariat, 2004.

56 International Centre for Settlement of Investment Disputes. Suggested Changes to The ICSID Rules and Regulations. ICSID Secretariat, 2005, par. 4. 
Nowadays, more than a decade after the first attempt to reform, censures to the traditional ISDS continue to emerge and have become more notorious in the case law. In contrast, the need for amendments is no longer premature, opening the door for a second attempt to reform, this time promoted under the auspices of the European Union, today's largest provider and destination of FDI in the global economy. ${ }^{57}$

In this sense, the EU "has seized the opportunity to reform the traditional arbitration-based system and replace it with a permanent court system" ${ }^{58}$ This constitutes an innovative mechanism intended to address some of the core issues discussed in the previous chapter, by combining elements of the traditional ISDS with judicial features.

Hence, this chapter deals with the inclusion of the EU's new investment policy in ongoing IIAs negotiations, the core institutional features of the ICS, and the prospect of a future Multilateral Investment Court for the application of the new approach across the globe.

\subsection{The EU's new investment policy}

In 2009, with the entry into force of the Lisbon Treaty, the Member States of the European Union added "foreign direct investment" to the terms of article 207(1) of the TFEU and, consequently, gave the competence to the EU - as a unit - for negotiating and concluding agreements protecting foreign direct investments in all sectors.

This arrangement constituted a significant transformation in the EU's investment policy in many ways. First, it implied the end of the traditional practice of the EU Member States of concluding investment agreements with third States on an individual basis. Second, it set the ground for the adoption of a single and comprehensive approach to the foreign investment regime. Third, it guaranteed public scrutiny over any future trade agreement in Europe by adopting a right of veto of the European Parliament. ${ }^{59}$

This new political framework presented an ideal platform for the EU to promote an unprecedented shift in its forthcoming foreign investment policy and thus, in shaping the future of the foreign investment regime. Under these circumstances, the EU's new investment policy aims at a more consistent, impartial and transparent system, achievable in its view by the introduction of

57 See: http://ec.europa.eu/trade/policy/accessing-markets/investment/index_en.htm (Accessed 19 May 2018).

58 Lenk, H. An Investment Court System for the New Generation of EU Trade and Investment Agreements: A Discussion of the Free Trade Agreement with Vietnam and the Comprehensive Economic and Trade Agreement with Canada. European Papers. Vol. 1, 2016, 665. Available at: http://www.europeanpapers.eu/en/europeanforum/investment-court-system-new-generationeu-trade-and-investment-agreements (Accessed 16 July 2017).

59 Коетн. Can the Investment Court System (ICS) Save tTIP and CETA, cit., 6. 
an Investment Court System for the resolution of investment-related disputes, which merges features of arbitration and judicial settlement.

To this date, the ICS has been already included in most recent FTAS entered into by the EU, while suggested in others currently in negotiation.Accordingly, in September 2015, the European Commission's draft text of the Transatlantic Trade and Investment Partnership (TTIP), which was complemented in November 2015 , constituted the first IIA to include the ICS as the mechanism of dispute settlement. Subsequently, in January 2016, the ICS was implemented in the EU-Vietnam FTA, followed by the EU-Canada Comprehensive Economic and Trade Agreement (CETA) in February $2016 .{ }^{60}$ More recently, in April 2018, the ICS has been incorporated in both the EU-Singapore Investment Protection Agreement and the EU-Mexico Trade Agreement, while negotiations are being hold for its inclusion in the EU-Japan Economic Partnership Agreement.

\subsubsection{The Transatlantic Trade and Investment Partnership (TTIP)}

In March 2014, the European Commission launched an online public consultation on investment protection and ISDS in the TTIP, followed by a report with the results, published in January 2015, in which the Commission revealed an overwhelming public discontent with the arbitral tribunals conducted under the ISDS. ${ }^{61}$

In response to this, in May 2015, the Commission, led by its Trade Commissioner, Cecilia Malmoström, who had previously criticised the ISDS model by referring to the need of establishing "the rule of law, not the rule of lawyers" ${ }^{62}$ issued a concept paper entitled "Investment in TTIP and beyond - the path for reform", which inaugurated the possibility of introducing a permanent international investment court system for the resolution of investment-related disputes in the TTIP. ${ }^{63}$

Following this, in September 2015, the Commission revealed an informal draft text for the TTIP including the introduction of the ICS, which was then transferred to the formal proposal made public in November 2015 for negotiation with the United States. In the event of approval, considering the investment network of the two parties, it would certainly shape the future of

60 ReInIsch, A. Will the EU's Proposal concerning an Investment Court System for CETA and TTIP lead to Enforceable Awards? - The Limits of Modifying the ICSID Convention and the Nature of Investment Arbitration. Journal of International Economic Law. Vol. 19, 2016, 761762.

61 Report Presented Today: Consultation on Investment Protection In EU-US Trade Talks - Trade - European Commission (Trade.ec.europa.eu, 2017). Available at: http://trade.ec.europa. eu/doclib/press/index.cfm?id=1234 (Accessed 6 July 2017).

62 European Commission. Discussion on Investment in TTIP at the Meeting of the International Trade Committee of the European Parliament. 2015. Available at: http://europa.eu/rapid/ press-release_SPEECH-15-4624_en.htm (Accessed 10 July 2017).

63 Malmström. Concept Paper: Investment in tTIP And Beyond - The Path for Reform, cit. 
investment dispute settlement. Nonetheless, negotiations were halted in late 2016 amid strong opposition from various sectors, although representatives of both parties have expressed willingness to resume bilateral talks.

\subsubsection{The EU-Vietnam Free Trade Agreement}

As stated above, the Commission's proposal to substitute the traditional ISDS with the ICS was not limited to the TTIP but intended to encompass all future EU trade agreement. Accordingly, in December 2015, the Commission announced, through a press release, that negotiations on the EU-Vietnam FTA had concluded, and that States parties had agreed on including the ICS as the mechanism for the resolution of investment disputes. ${ }^{64}$

Although this announcement constituted a significant confirmation of the new roadmap drawn by the EU's investment policy, it received little attention from the public outside the investment law community. ${ }^{65}$

\subsubsection{The EU-Canada Comprehensive Economic and Trade Agreement (CETA)}

Furthermore, in February 2016, the Commission announced through a press release $^{66}$ that CETA's negotiating parties had decided to revise the previously agreed version of the treaty, in order to replace the originally conceived ISDS with the ICS, following the outline provided for the TTIP formal proposal and recent integration in the final text of the EU-Vietnam FTA.

In regard to CETA's first version, which had conceived the ISDS, it was considered as the cutting-edge development of investment protection "containing all possible safeguards against an abuse of the system by profit-seeking corporations at the expense of citizens and governments" ${ }^{67}$ In particular, it included clear definitions of key concepts such as 'indirect expropriation' and 'FET', as well as a far-reaching preamble balancing the protection of investor's rights with the promotion of sustainable development, labour, environmental and human rights protection, and an express exception endorsing the States' regulatory power on matters of public health, the environment, public order and morality. Nevertheless, the first version failed to address one of the most criticised aspects of the system, namely the ISDS, perceived by the public as

64 European Commission. The EU and Vietnam Finalise Landmark Trade Deal. 2017. Available at: http://trade.ec.europa.eu/doclib/press/index.cfm?id=1409 (Accessed 9 July 2017).

65 LENK. An Investment Court System for the New Generation of EU Trade and Investment Agreements, cit., 666.

66 European Commission. CETA: EU and Canada Agree on New Approach on Investment in Trade Agreement. 2016. Available at: http://europa.eu/rapid/press-release_IP-16-399_en.htm (Accessed 12 July 2017).

67 Kоетн. Can the Investment Court System (ICS) save TTIP and CETA, cit., 8. 
a mechanism which allegedly allowed private parties to force States to pay vast sums of money at the expense of public resources. ${ }^{68}$

Under these circumstances, the adoption of the 2016 revised version of CETA constituted a response to the critiques by introducing a major shift in investment dispute settlement in the form of a comprehensive agreement with Canada, a culturally alike partner of the EU. This revised version is also expected to be adopted with the US, and thus cover a significant amount of world trade relations and develop into the default standard for any future investment agreement worldwide. ${ }^{69}$

Given that CETA was approved by the European Parliament and has become the first IIA adopting the ICS entering into force, it has established the yardstick - for both critics and supporters - of the EU's new approach in investment policy.

Notably, the Regional Parliament of Wallonia (Belgium), which has a veto over Belgium's consent to trade agreements, objected to the signature of CETA, demanding stronger safeguards on labour, environmental and consumer standards and criticising the investment chapter. ${ }^{70}$ Although Belgium finally provided its consent, this was conditioned to requesting an opinion from the Court of Justice of the European Union (ECJ) concerning the compatibility of the proposed investment court system with EU law, which Belgium submitted on 6 September 2017. ${ }^{71}$ Though CETA provisionally entered into force on 21 September 2017, its ratification in Belgium is conditioned to a positive answer from the ECJ. In this context, some commentators consider that a negative answer from the ECJ may not only exclude the investment chapter but hinder the institution of a multilateral investment court system in Europe. ${ }^{72}$

\subsubsection{The EU-Singapore Investment Protection Agreement}

On 18 April 2018, after eight years of bilateral talks, the European Commission made public the conclusion of a Free Trade Agreement (FTA) and an Investment Protection Agreement (BIT) between the EU and Singapore.

The EU-Singapore BIT represents an important benchmark towards setting investment protection standards for the Southeast Asian region, while opening the door for a region-to-region agreement between the EU and the Association of Southeast Asian Nations (ASEAN), to which Singapore is a member

68 Ibid.

69 Ibid.

70 See: https://www.bbc.co.uk/news/world-europe-37749236 (Accessed 19 July 2017).

71 See: https://diplomatie.belgium.be/en/newsroom/news/2017/minister_reynders_submits_request_opinion_ceta (Accessed 8 September 2017).

72 See: http://arbitrationblog.practicallaw.com/update-on-the-european-commissionsdrive-for-investment-courts/ (Accessed 12 January 2018). 
State ${ }^{73}$ Overall, the agreement contains all aspects of the EU's new approach to investment protection and its enforcement mechanisms, including: (i) a Permanent Investment Tribunal of First Instance to hear investment claims, whose members will be appointed in advance by the EU and Singapore, subject to rigorous rules of independence and directed by a binding code of conduct included in the agreement; ${ }^{74}$ and (ii) a Permanent Appeal Tribunal to hear appeals from provisional awards issued by the First Instance Tribunal. ${ }^{75}$

Moreover, the agreement paves the way to the establishment of a multilateral investment tribunal and appellate mechanism for the resolution of international investment disputes with other trading partners, subordinating its dispute settlement provisions to those agreed in a future multilateral mechanism. ${ }^{76}$

\subsubsection{The EU-Mexico Trade Agreement}

Shortly after, on 21 April 2018, the EU announced the conclusion of a new EU-Mexico Trade Agreement, intended to deepen and broaden the existing network of trade and investment between the parties.

Likewise, this agreement implements the EU's new approach to investment protection and dispute resolution by replacing the traditional ISDS system with the new ICS. ${ }^{77}$ In this way, the inclusion of the ICs in yet another trade agreement reinforces the EU's attempt to 'modernise' the framework of investment protection by introducing more judicial-alike features to hear such disputes, while advancing towards an ultimately envisaged Multilateral Investment Court System.

\subsection{The core institutional features of the ICS}

From an institutional perspective, the ICS implemented significant changes to the traditional ISDS. First, by establishing a first instance permanent tribunal with publicly appointed members, as opposed to the traditional panel of arbitrators selected by the parties. Second, by introducing an appellate tribunal, as opposed to the limited grounds provided for the challenge of

73 European Commission, Memorandum: 'Key Elements of the EU-Singapore Trade and Investment Agreements'. 2018. Available at: http://trade.ec.europa.eu/doclib/press/index. cfm?id=1827 (Accessed 8 July 2018).

74 Article 3.9, EU-Singapore Investment Protection Agreement.

75 Article 3.10, EU-Singapore Investment Protection Agreement.

76 Article 3.12, EU-Singapore Investment Protection Agreement.

77 European Commission. Memorandum: 'Key features of the EU-Mexico trade agreement'. 2018. Available at: http://trade.ec.europa.eu/doclib/press/index.cfm?id=1831 (Accessed 8 July 2018). 
awards before the Annulment Committee under ICSID framework or the setting aside procedure before national courts in non-ICSID cases.

Given that the TTIP, EU-Vietnam FTA and CETA could be grouped as the initial attempt to incorporate the EU's new investment approach, subsequently reproduced in the forthcoming agreements, the analysis of the main institutional features of the ICS will be reviewed in light of these three.

\subsubsection{The First Instance Tribunal}

The configuration of a judicial-alike structure is one of the most remarkable differences between the ISDS and the ICS. In this sense, while the traditional ISDS allows the parties to appoint the arbitrators on an ad hoc basis, the ICS provides for a panel of permanent members, transferring the right to appoint the adjudicators to the respondent States prior to the existence of a dispute. ${ }^{78}$

Regarding the Tribunal's composition, for TTIP, the proposed ICS would establish a Tribunal of First Instance composed of fifteen judges,${ }^{79}$ appointed for terms of six years, renewable once. ${ }^{80}$ In the case of the EU-Vietnam FTA, it provides for nine members of the Tribunal by equal participation, three being Vietnam nationals, three nationals of EU Member States, and the other three are third-country nationals.$^{81}$ In regard to CETA, it stipulates a total of fifteen members of the Tribunal with a similar even distribution, five Canadian members, five members from EU Member States, and the remaining five represented by nationals of third countries, ${ }^{82}$ for a renewable five-year term. In terms of nomenclature, it is interesting that only the TTIP proposal uses the term 'judges', whereas CETA and the EU-Vietnam FTA limit the reference to members of the Tribunal..$^{83}$

Furthermore, the selection of the respective national members is delegated to special committees created under the agreements. Accordingly, the EUVietnam establishes the Trade Committee, composed of the Minister of Trade and Industry of Vietnam and the EU Trade Commissioner, and similarly, CETA creates the Joint Committee ${ }^{84}$ integrated by the Minister for International

78 The Shortcomings of the Proposal for an "International Court System" (ICS). EFILA Blog, 2017. Available at: https://efilablog.org/2016/02/02/the-shortcomings-of-the-proposalfor-an-international-court-system-ics/ (Accessed 16 July 2017).

79 Article 9 (2), тTIP (EU's Proposal).

80 Article 9 (5), TTIP (EU's Proposal).

81 Article 12 (2), EU-Vietnam FTA.

82 Article 8.27 (2), CETA.

83 LENK. An Investment Court System for the New Generation of EU Trade and Investment Agreements, cit., 669.

84 Article 12, para. 2, respective Article 13, para. 2, EU-Vietnam FTA; Article 8.27, para. 2 , respective Article 8.28, para. 7, let. f), CETA. 
Trade of Canada and the EU Trade Commissioner. In both cases, the appointment must be reached by mutual consent. ${ }^{85}$

Moreover, individual cases shall be decided by divisions of three members of the Tribunal with the third-country national presiding over ${ }^{86}$ Although this arrangement might appear similar to the traditional ISDS, its uniqueness feature derives from the case-allocation mechanism commonly found in domestic judicial systems: "the three Members of the Tribunal are to be appointed by the President of the Tribunal on a yet-to-be specified "random and unpredictable' rotation system" ${ }^{87}$ This setting, based on a rotation scheme rather than nationality, is intended to tackle the lack of impartiality as it prevents the contesting parties from having influence in the composition of the panel. For instance, in the case of the EU-Vietnam FTA, the members of the Tribunal hearing the case are not required to have Vietnamese nationality. ${ }^{88}$ In a similar fashion, CETA follows this pattern of rotation when appointing individual cases. ${ }^{89}$

Furthermore, in order to ensure a disposition to perform their role, members of the Tribunal are paid a retainer fee on a monthly basis by the contracting parties..$^{90}$ This way, the TTIP sets an approximate of $€ 2,000$ retainer fee per month, ${ }^{91}$ whereas in the EU-Vietnam FTA and CETA is yet to be determined by their respective special committees. ${ }^{92}$

\subsubsection{The Appellate Tribunal}

The ICs establishes a two-level judicial structure, which means that awards rendered in the first instance can be appealed to the Appellate Tribunal. In this way, by introducing an appellate mechanism, specialists expect to "prevent the inconsistencies in decision-making and avoid the haphazard domestic frameworks that currently come into play in investment arbitration practice", and also "bring about more cohesion and more legal certainty to this body of law". ${ }^{3}$

85 CETA, Article 26.3, para. 3; the EU-Vietnam FTA refers to decision making by "mutual agreement", Article X.5, para. 3, Chapter on Institutional, General and Final Provisions.

86 Article 12, para. 8, EU-Vietnam FTA; Article 8.27, para. 8, CETA.

87 REINISCH. Will the EU's Proposal concerning an Investment Court System for CETA and TTIP lead to Enforceable Awards?, cit., 764.

88 Footnote 25 and 26, EU-Vietnam FTA.

89 Footnote 9, CETA.

90 Article 8.27.12 and 8.27.13, CETA.

91 Article 9, para. 12, тTIP (EU's Proposal).

92 Article 12, para. 14, and Article 13, para. 14, EU-Vietnam FTA; Article 8.27, para. 12, and Article 8.28, para. 7, let. d), CETA.

93 BUTLER. Possible Improvements to The Framework of International Investment Arbitration, cit., 632 . 
In regard to the composition of the Appellate Tribunal, the EU-Vietnam FTA provides for six members, following the same tripartite distribution articulated for the First Instance Tribunal, this is: two EU nationals, two Vietnam nationals and two third-country nationals. ${ }^{94} \mathrm{CETA}$, on the other hand, does not specify the exact number of members to comprise the Appeal Tribunal, but leaves this aspect to be determined by the Joint Committee under the condition of it being a division of three. ${ }^{95}$ As for the TTIP proposal, the Appellate Tribunal would be composed of six members, also appointed by the contracting parties. ${ }^{96}$

In line with the First Instance Tribunal, the individual case assignation for appeals is determined on a rotational basis, and not on nationality. Nevertheless, such reference is not expressly included in the provision governing the appointment of members of the Appeal Tribunal in CETA..$^{97}$

Noteworthy, the installation of an appeal facility allows the possibility to challenge an award within 90 days of its issuance..$^{8}$ This increases the grounds for challenge and includes errors in the interpretation or application of the law as well as manifest error in the appreciation of the facts, ${ }^{99}$ thus guaranteeing correctness and predictability. Based on these grounds, the Appeal Tribunal may either: reject the appeal, in which case the Tribunal award becomes final; ${ }^{100}$ or uphold the appeal, in which case it can modify - entirely or partially - the award ${ }^{101}$ or reverse the legal findings for the first instance to issue a revised award. ${ }^{102}$

\subsection{The venture towards a Multilateral Investment Court}

Since the publication of the 2015 Trade Commissioner concept paper "Investment in TTIP and beyond - the path for reform", the EU has exposed its ultimate objective of pursuing the establishment of a single multilateral permanent court applicable to multiple agreements and trading partners from all around the globe. In this sense, Commissioner Malmoström stated that "[t]he objective would be to multilateralize the court either as a self-

94 Article 13, para. 2, EU-Vietnam FTA.

95 Article 8.28, para. 5, CETA.

96 Article 10 (2), тTIP (EU's Proposal).

97 Footnote 9, CETA.

98 See Article 8.28(9)(a) revised text of CETA, above n 3; Article 29(1), section 3, EU's proposal, ibid; Article 28(1), section 3, EU-Vietnam FTA Investment Chapter, above n 1.

99 Article 28, para. 1, EU-Vietnam FTA; Article 8.28, para. 2, CETA.

100 Article 29(2), section 3, EU's proposal, ibid; Article 8.28(9)(c)(ii) revised text of CETA, ibid; Article 29(2), section 3, EU-Vietnam FTA Investment Chapter, ibid.

101 Article 29(2), section 3, TTIP (EU's Proposal); Article 8.28(2) revised text of CETA, ibid; Article 28(3), section 3, EU-Vietnam FTA Investment Chapter.

102 Article 28(7), section 3, EU's proposal, ibid; Article 29(4), section 3, EU-Vietnam FTA Investment Chapter, ibid; Article 8.28(7)(b) revised text of CETA, ibid. 
standing international body or by embedding it into an existing multilateral organization". ${ }^{103}$

This proposal is feasible when considering EU's goal of including the ICS in every future trade agreement, particularly by its inclusion in CETA and potentially in TTIP, which would cover a significant portion of the world's source of FDI. Therefore, the introduction of ICs's features in all EU trade and investment agreements would not only mark the departure from the traditional ISDS but the opening wedge towards the consolidation of a single multilateral permanent court operating under a two-tier judicial structure to settle investment disputes.

In fact, experts tend to agree that "a single, preferably institution-allymanaged and widely-accepted mechanism for reviewing investor-state arbitral awards would be best suited to address the risk of fragmentation of the dispute settlement system that might otherwise ensue". ${ }^{104}$ Therefore, the future of a multilateral permanent investment court seems to be a further step in achieving a more consistent and predictable case law and thus, enhancing the legitimacy of the investment regime.

Interestingly, in Article 8.29 of CETA, the EU and Canada confirmed their interest to pursue the establishment of a multilateral investment court in future agreements with other non-contracting trading parties. Similarly, Article 12 of the proposed TTIP text contemplates the possibility of moving to a multilateral investment tribunal and/or a multilateral appellate mechanism, which if agreed, would subsume the relevant dispute settlement provisions.

\section{CRITICISM TO THE ICS}

Despite the series of institutional and procedural innovations described above, the ICS is subject to censure from several scholars and sceptical practitioners. This chapter addresses some of the focal drawbacks foreseen by its detractors.

\subsection{Re-politicisation}

The ICs aims at tackling the problems associated with the lack of impartiality in the ISDS by preventing parties from participating in the appointment of the panel hearing their case. However, some experts argue that such modification introduces a political component that may jeopardise the progress accomplished in terms of de-politicisation of investment disputes, considered one of the

103 Malmström. Concept Paper: Investment in TtiP And Beyond - The Path for Reform, cit., 11.

104 Gleason, E. E. International Arbitral Appeals: What Are We So Afraid Of? Pepperdine Dispute Resolution Law Journal. Vol. 7, 2007, 286. Available at: http://digitalcommons. pepperdine.edu/drlj/vol7/iss2/5 (Accessed 17 July 2017). 
greatest achievements of the system. ${ }^{105}$ In this way, the random composition of the Panel hearing the case not only removes the opportunity of disputing parties to appoint a neutral Tribunal but also unduly empowers a politically designated organ - the Joint Committee - to take over the selection process in disguise of impartiality.

The risk of re-politicisation is further accentuated with the introduction of the appellate structure. In this sense, given the often-sensitive issues at stake " $[\mathrm{t}]$ here is concern that host state governments are likely to appeal every case lost at first instance, in order to gain favour with their constituents". ${ }^{106}$ It follows, therefore, that governments would be forced to appeal as a result of the pressure from their citizens and to their political agenda. Likewise, investors would follow the tendency to appeal adverse decisions due to similar pressures from their shareholders ${ }^{107}$.

In response to the above, supporters of the ICs have come up with the idea of demanding securities in the form of a deposit or bond in order to access the appeal facility, which in turn may play a twofold purpose: on the one hand, it would disincentivise the erratic appellant; on the other hand, it would offer a reinforced guarantee of compliance with the final award. ${ }^{108}$

Furthermore, some critics point out the paradox of transferring the right of appointment exclusively to sovereign States, which - through the prism of the State-appointed Joint Committee - would be ultimately selecting proStates oriented members of the permanent tribunal. In this sense, one may ask: "[i]f the concern was that private business lawyers serving as arbitrators have a natural bias towards enterprises, could government-appointed judges not also be suspected of having a natural bias towards the state, in particular their own?". ${ }^{109}$ In this context, although the ICS would certainly rebalance the equation, it may improperly favour the interest of the host States rather than finding the sought point of equilibrium between the parties.

\subsection{Quality of the decision-making}

Some critics assert the lack of financial incentives to attract high-profile individuals comprising the permanent tribunal. In this sense, they fear that, similar to the experience with the introduction of the wTO Appellate Body, States may be reluctant to allocate sufficient financial resources for permanent

105 LENK. An Investment Court System for the New Generation of EU Trade and Investment Agreements, cit., 669.

106 BuTLER. Possible Improvements to The Framework of International Investment Arbitration, cit., 635 .

107 Коетн. Can the Investment Court System (ICS) Save tTIP and CETA, cit., 12.

108 BUTLER. Possible Improvements to The Framework of International Investment Arbitration, cit., 636.

109 Коетн. Can the Investment Court System (ICS) Save tTIP and CETA, cit., 12. 
members, and thus "[r]ather than attracting the most qualified experts, positions [would be] more likely to be filled by political appointees. ${ }^{110} \mathrm{Hence}$, by not having the best possible panel of arbitrators, the decision-making process may reduce in quality, efficiency and reliability.

Moreover, there is no conclusive evidence to support the assertion that government-appointed members of the permanent tribunal would exercise a more competent, objective and impartial duty than those appointed by the parties in the current ISDS. ${ }^{111}$ In fact, to this date, it is indisputable that the quality of the arbitrators and awards under the ISDs has been extraordinarily high as a general rule.

A further concern related to the introduction of an appellate body is that it may undermine the authority of the first instance decision. In such manner, given the expected proclivity to appeal against the decisions of first instance, the latter are likely to be devalued. ${ }^{112}$ Consequently, high-profile arbitrators would be reserved for the appellate body, jeopardising a highly technical and efficient mechanism for dispute settlement.

Additionally, the fact that the panel hearing the case would be selected randomly from a pool of permanent members of the tribunals, would eliminate the opportunity of the parties to appoint experts in the precise - and often complex, interdisciplinary and highly technical - matter of dispute between the parties.

\subsection{Finality, efficiency and costs}

Another source of criticism to the ICS derives from the alleged negative impact it would have on the finality of the awards, which in turn is perceived as one the main benefits of the ISDS. In this sense, experts fear that the introduction of an instance of appeal would enhance the restricted grounds currently in place to challenge investment awards. ${ }^{113}$

Nonetheless, supporters of the ICS have argued that given the public policy issues often at stake in investment arbitration, it is necessary to reinforce the correctness of faulty decisions even if this might, in turn, sacrifice the finality of the awards. ${ }^{114}$ In other words, correctness should not be subordinated to finality, particularly when public interests are at stake.

Furthermore, critics to the ICS assert that the parties' right to appeal would negatively impact the delivery of efficient decisions, generating a domino

110 Ibid., 12.

111 Ibid., 13.

112 TAMS. Is there a Need for an ICSID Appellate Structure?, cit., 229.

113 BuTLER. Possible Improvements to The Framework of International Investment Arbitration, cit., 634.

114 Ibid., 635. 
effect by lengthening the process and increasing significantly the costs of the proceedings.

Concerning the time-frame, those opposing the ICS stress that an appellate structure would naturally extend the period of time before a definitive decision is reached. Logically, adjudication in a two-tiered system would take longer than in a single round of proceedings. Although this elongation of the proceedings would certainly depend on the time-frames to be established on a case-by-case basis, it seems natural to assert that regardless of the configuration of the appeal body, its introduction would hinder the efficient resolution of disputes. ${ }^{115}$

In contrast with the above, supporters of the ICS have claimed that the current rules regarding annulment proceedings within ICSID framework and the review-mechanism through national courts in non-ICSID awards, already causes considerable delays in the proceedings. Consequently, an appellate body would in fact contribute to accelerating the process by adopting strict time-limits. ${ }^{116}$

In regard to the alleged increase in costs, "based on a simple calculation: the longer the proceedings, the higher the costs" ${ }^{117}$ This is particularly reflected in the additional attorney's fees, which in fact constitutes the greatest expense in the arbitration process. ${ }^{118}$ Consequently, it may only benefit governments, large corporations and wealthy individuals with a strong financial muscle to finance the team of legal experts.

Conversely, advocates of the ICs have argued that the new process would be cheaper compared to the current costs incurred in annulment proceedings or challenges before national courts of the seat of arbitration or place of enforcement. ${ }^{119}$

Finally, detractors of the ICS foreshadow an increase in cases being challenged by the losing party, which would affect the reliability of the system. In response to this, as previously discussed, defenders of the ICs call for the adoption of measures to discourage appeals and to guarantee the compliance of awards. ${ }^{120}$

115 TAMs. Is there a Need for an ICSID Appellate Structure?, cit., 228.

116 ButLER. Possible Improvements to The Framework of International Investment Arbitration, cit., 635 .

117 TAMs. Is there a Need for an ICSID Appellate Structure?, cit., 228.

118 LaIRD, I. and Askew, R. Finality versus Consistency: Does Investor State Arbitration Need an Appellate System? The Journal of Appellate Practice and Process. Vol. 7, 2005, 298.

119 BUTLER. Possible Improvements to The Framework of International Investment Arbitration, cit., 635 .

120 Ibid., 635. 


\subsection{Enforceability}

Some experts and practitioners have questioned the potential recognition and enforceability of the decisions rendered under the ICs, arguing a lack of compatibility with ICSID and UNCITRAL procedures. ${ }^{121}$ This is due to the configuration of the ICS as a judicial structure rather than an arbitral institution, which make some consider that neither the Washington Convention nor the New York Convention would be applicable to it. ${ }^{122}$

Furthermore, while it is certainly debatable whether a 'semi-permanent arbitration body' would be considered to be a court or an arbitral tribunal, it is also true that, in the realm of international arbitration, mixed structures do exist, and the New York Convention has recognised that these are capable of rendering enforceable awards. The most notorious example of this is the Iran-United States Claims Tribunal, established in 1981, which provided for the appointment of judges by the United States and Iran to settle cases between their nationals. ${ }^{123}$ To date, the Tribunal has finalised more than 3,900 cases $^{124}$ and is currently active.

In regard to the ICSID framework, amendment of the Convention might turn awards of ICS tribunals into genuine ICSID awards providing the full applicability of the Convention's enforcement provisions. Alternatively, any potential modification of the ICS - provided it is compatible with the object and purpose of the Convention - would lead to the substitution of the ISDS as the mechanism to resolve investment-related disputes but this would be only applicable to the contracting parties of the respective investment agreement. It follows, therefore, that third States parties to ICSID would not be affected by such modification and, consequently, would not have enforcement obligations unless the EU and its trading partners include specific provisions for the recognition and enforcement of investment agreements with them. ${ }^{125}$

In relation to the New York Convention, the critical issue would be "whether national courts in New York Convention contracting States, where recognition and enforcement may be sought in the future, [would] consider ICs awards as awards made by an arbitral body". ${ }^{126}$ In this sense, as referred above, although it seems likely that the ICS would remain a form of mixed arbitration, and thus render enforceable awards under the New York Convention, operators may

121 Collins. The UK should include Investor State Dispute Settlement (ISDS) in its PostBrexit International Investment Agreements, cit., 15.

122 LENK. An Investment Court System for the New Generation of EU Trade and Investment Agreements, cit., 670.

123 REINISCH. Will the EU's Proposal concerning an Investment Court System for CETA and TTIP lead to Enforceable Awards?, cit., 767.

124 See official website: http://www.iusct.net/ Accessed 31 March 2018.

125 Ibid., 782.

126 Ibid., 786. 
bear in mind that some national courts may reach the opposite conclusion, at risk of jeopardising the enforceability of the decisions. ${ }^{127}$

\section{CONCLUSIONS}

In an ever more globalised world and economic marketplace, the advent of the investor-state-dispute settlement has reinforced the rule of law by offering foreign investors a legal-route to shield their investments against host States' measures and omissions that may fail to meet international standards of treatment. In exchange, it has allowed States to promote a more attractive investment environment to invite foreign direct investment, and thus, foster economic growth.

In spite of its notable benefits as a means of international dispute settlement, including efficiency, flexibility, finality and a comprehensive enforcement structure, the current ISDS is far from ideal. In a broad sense, it could be said that its structural deficiencies are the result of attempting to reproduce a dispute settlement model conceived for the resolution of private commercial disputes, rather than it being tailored for disputes involving public policy and public law matters. Accordingly, far-reaching reforms in the pursuit for consistency, impartiality and transparency are required in order to strengthen the legitimacy of the system.

Nevertheless, it ought to be acknowledged that over the past few years the ISDS has undergone a series of reforms that have already counteracted most of the concerns that the introduction of the ICS is intended to remedy. As a result, criticisms to the ISDS must take into account the latest developments from arbitral houses, international practice guidelines and a new generation of investment treaties that have contributed to a remodelled ISDS.

For instance, the first version of CETA, which originally adopted ISDS as the mechanism for the resolution of investment disputes, was considered a state-of-the-art investment agreement, providing for, inter alia, express exceptions confirming the right of the State regulatory powers on the grounds of public health, public order, morality and the environment, thus tackling some of the issues associated with the alleged pro-investor affinity of the system.

Additionally, arbitral institutions and rules have predominantly followed a wide-reaching pro-transparency campaign in investment arbitration, which has led to recent amendments to ICSID and UNCITRAL procedural rules, including the implementation of public hearings and, as a general rule, making publicly available the communications from the Tribunal, the submissions of the parties and the rendering of the awards.

Furthermore, although arbitral tribunals cannot be said to be bound by previous decisions, there is no doubt that landmark awards are regarded by

127 Ibid. 
arbitrators as persuasive authority. Therefore, in response to critics concerned with the lack of consistency, a de facto doctrine of precedent is already in place in the ISDS, which is encouraged by the public accessibility to the awards and the well-established practice of referring to the legal reasoning of other tribunals - both by counsel and arbitrators - in order to reinforce a given legal point and support the tribunal's decision.

Although improvements to the ISDS model are still required in order to effectively meet the prospect of a more consistent, impartial and transparent means of dispute settlement, these reforms could take place within the ISDS framework, instead of abandoning it entirely. Moreover, by continuing the path of reforms to the current ISDS, together with the implementation of all possible safeguards against potential abuse of the investment regime, disputing parties may be able to maintain an effective, flexible, final and easily enforceable means of dispute settlement that has been subject to international scrutiny, while continuing to improve its legitimacy and consistency.

In contrast, although the introduction of the ICS virtually addresses the ISDS's deficiencies, it may also bring more uncertainty to the system, while opening the door to other structural difficulties such as the risk of re-politicisation of the system, the potential decrease in quality of the decisions, the ambiguous consequences to the finality, efficiency and costs of the proceedings, and the threat to the enforceable structure in place for arbitral awards. Besides, it should be noted that some of the acclaimed innovations, such as the code of conduct for members of the tribunal, will be only implemented after the establishment of the Court, which means it needs underlying monitoring and review.

Finally, it should be mentioned that the introduction of the ICs has raised tensions within the EU concerning the compatibility of the ICS with the principle of autonomy of the EU legal order, which will be ultimately decided by the CJEU. Following the Achmea case, this will be another controversial decision that will certainly shape the future of the EU's investment policy and the subsequent implementation of a multilateral investment court system of global scale.

\section{REFERENCES}

\section{Literature}

Butler, N. Possible Improvements to the Framework of International Investment Arbitration. The Journal of World Investment \& Trade. Vol. 14, 2013.

Collins, D. The UK should include Investor State Dispute Settlement (ISDS) in its PostBrexit International Investment Agreements. 2017. sSRN Electronic Journal: https:// ssrn.com/abstract $=2924051$ 
GleAson, E. International Arbitral Appeals: What are we so afraid of? Pepperdine Dispute Resolution Law Journal. Vol. 7, 2007. Available at: http://digitalcommons.pepperdine. edu/drlj/vol7/iss2/5 (Accessed 17 July 2017).

Horvath, G. J. and Berzero, R. Arbitrator and Counsel: The Double-Hat Dilemma.Transnational Dispute Management (TDM). 2017. Available at: https://www.transnationaldispute-management.com/article.asp?key=1985 (Accessed 19 August 2017).

Koeth, W. Can the Investment Court System (ICS) save TTIP and CETA. European Institute of Public Administration (EIPA) Working Papers. 2016. Available at: http://publications. eipa.eu/en/details/\&tid=1860 (Accessed 16 July 2017).

LaIrd, I. and Askew, R. Finality versus Consistency: Does Investor State Arbitration need an Appellate System? The Journal of Appellate Practice and Process. Vol. 7, 2005.

Lenk, H. An Investment Court System for the New Generation of EU Trade and Investment Agreements: A Discussion of the Free Trade Agreement with Vietnam and the Comprehensive Economic and Trade Agreement with Canada. European Papers. 1, 2016. Available at: http://www.europeanpapers.eu/en/europeanforum/investment-courtsystem-new-generation-eu-trade-and-investment-agreements (Accessed 16 July 2017).

Mann, H. et al. Comments on ICSID Discussion Paper, "Possible Improvements of the Framework for ICSID Arbitration”. International Institute for Sustainable Development (IISD), 2004.

ReInIsch, A. Will the EU's Proposal Concerning an Investment Court System for CETA and TTIP Lead to Enforceable Awards? - The Limits of Modifying the ICSID Convention and the Nature of Investment Arbitration. Journal of International Economic Law. Vol. 19, 2016.

Stone Sweet, A., Chung, M. and Saltzman, A. Arbitral Lawmaking and State Power: An Empirical Analysis of Investment Arbitration. Available at: https://ssrn.com/abstract=2919723 (Accessed 17 July 2017).

TAMS, C. Is there a Need for an ICSID Appellate Structure? 2009. sSRN Electronic Journal: https://ssrn.com/abstract=1341268

Van Harten, G. Arbitrator Behaviour in Asymmetrical Adjudication (Part Two): An Examination of Hypotheses of Bias In Investment Treaty Arbitration. Osgoode Hall Law Journal. Vol. 50, 2012.

Webb Yackee, J. Toward a Minimalist System of International Investment Law. Suffolk Transnational Law Review. 303, 2009.

Case Law

CME Czech Republic B.V. v. Czech Republic. uncitral Rules, Award, 14 March 2003.

Lauder v. Czech Republic. uncitral Rules, Final Award, 3 September 2001.

SGS Société Générale de Surveillance S.A. v. Islamic Republic of Pakistan. ICsid Case No. ARB/01/13. Decision on Jurisdiction, 6 August 2003. 
SGS Société Générale de Surveillance S.A.v. Republic of the Philippines. ICsid Case No. ARB/02/6. Decision on Jurisdiction, 29 January 2004.

Metalclad Corporation v. United Mexican States. ICSID Case No. ARB(AF)/97/1, Award, 30 August 2000.

S.D. Myers, Inc. v. Government of Canada. UnCITRAL Case, Partial Award, 13 November 2000 (NAFTA Arbitration).

Fábrica de Vidrios Los Andes, CA and Owens-Illinois de Venezuela v. Bolivarian Republic Venezuela. ICSID Case No. ARB/12/21.

\section{Reports, Press Releases and Internet Sources}

Arbitral Rules - Investment Dispute Settlement Navigator (Investmentpolicyhub.unctad. org, 2017). Available at: http://investmentpolicyhub.unctad.org/IsDs/FilterByRulesAndInstitution (Accessed 20 July 2017).

Process Overview (Icsid.worldbank.org, 2017). Available at: https://icsid.worldbank.org/ en/Pages/process/Overview.aspx (Accessed 6 July 2017).

ICSID Rules (Icsid.worldbank.org, 2017). Available at: https://icsid.worldbank.org/en/Pages/ icsiddocs/ICSID-Rules.aspx (Accessed 4 July 2017).

ICSID Additional Facility Rules (Icsid.worldbank.org, 2017). Available at: https://icsid. worldbank.org/en/Pages/icsiddocs/ICsID-Additional-Facility-Rules.aspx (Accessed 4 July 2017).

UnCTAD. Trade and Development Report. United Nations, 2014. Available at: http://unctad. org/en/PublicationsLibrary/tdr2014_en.pdf (Accessed 8 July 2017).

Malmström, C. Concept Paper: Investment in tTIP And Beyond - The Path for Reform. European Commission, 2015.

International Centre for Settlement of Investment Disputes. Possible Improvements of the Framework for ICSID Arbitration. ICSID Secretariat, 2004.

International Centre for Settlement of Investment Disputes. Suggested Changes to the ICSID Rules and Regulations. ICSID Secretariat, 2005.

Report Presented Today: Consultation on Investment Protection In EU-US Trade Talks Trade - European Commission (Trade.ec.europa.eu, 2017). Available at: http://trade. ec.europa.eu/doclib/press/index.cfm?id=1234 (Accessed 6 July 2017).

European Commission. Discussion on Investment in TTIP at the Meeting of the International Trade Committee of the European Parliament. 2015. Available at: http://europa.eu/ rapid/press-release_SPEECH-15-4624_en.htm (Accessed 10 July 2017).

Malmström, C. Concept Paper: Investment in tTiP And Beyond - The Path for Reform. European Commission, 2015.

European Commission. The EU and Vietnam Finalise Landmark Trade Deal. 2017. Available at: http://trade.ec.europa.eu/doclib/press/index.cfm?id=1409 (Accessed 9 July 2017). 
The Shortcomings of the Proposal for an "International Court System" (ICS). EFILA Blog, 2017. Available at: https://efilablog.org/2016/02/02/the-shortcomings-of-the-proposalfor-an-international-court-system-ics/ (Accessed 16 July 2017).

European Commission. CETA: EU and Canada Agree on New Approach on Investment in Trade Agreement. 2016. Available at: http://europa.eu/rapid/press-release_IP-16399_en.htm (Accessed 12 July 2017).

European Commission. Memorandum: 'Key elements of the EU-Singapore trade and investment agreements'. 2018. Available at: http://trade.ec.europa.eu/doclib/press/index. cfm?id=1827 accessed 8 July 2018 .

European Commission. Memorandum: 'Key features of the EU-Mexico trade agreement'. 2018. Available at: http://trade.ec.europa.eu/doclib/press/index.cfm?id=1831 (Accessed 8 July 2018).

Practical Law - Arbitration Blog. Update on the European Commission's Drive for Investment Courts. 2017. Available at: http://arbitrationblog.practicallaw.com/update-onthe-european-commissions-drive-for-investment-courts/ (Accessed 12 January 2018). 